\title{
Signifying Women - Politics of Gesture in Three Modern Dance Pioneers
}

\author{
By Heather Roffe Wiktorski*
}

Delving critically into the larger (or global) artistic, social and political climate of the environments and respective time periods that Isadora Duncan, Martha Graham, and Yvonne Rainer were actively creating work/performing in, I investigate the bodily politics and feminist discourses represented in the choreography of these 20th century modern dancer pioneers through an exigesis of literature and hermeneutical inquiry. By looking at three different generations/iterations of modern dance through a socio-historical lens, unique feminist and political choices are revealed in how they presented themselves publicly and through their dancing. I analyze how these three women negotiated and navigated the terrain of a male-dominated society and a marginalized art form, and through their gesturing bodies, produced latitudinal changes in how dance and women were perceived. Rather than extracting these women from their context of existence to look microscopically at just their choreography from a current frame of reference, I have attempted to weave them into the fabric of American history, measuring and assessing their advances in reference to these socio-historical findings. This research investigates the ideology of body politics, specifically of the female body, how these perceptions have necessarily changed over time, and the resulting aesthetic affect in regards to modern dance.

\section{Movements of Change}

In her book Moving Lessons, author Janice Ross observes that the "transition of the $\ldots 19^{\text {th }}$ century woman into the physically active, $20^{\text {th }}$ century New Woman is ... complex, for it involves the refutation of systems of belief about gender roles, the body, and the linkage of physicality, education, and culture." 1 While the $19^{\text {th }}$ century shift in social consciousness from the rational/ mechanical Age of Enlightenment to the irrational sentimentality of the Romantic period transitioned and translated to other art forms and aspects of life, in dance and on the site of the body, it was not such an easy course to navigate. The female body especially was fraught with warring notions of physicality versus ephemerality, naturality versus artificiality, and the classic versus the grotesque body. Despite the Romantic desire to achieve wholeness, the ongoing tension between the dualities of subjective/sentimental and objective/scientific axioms recalls the Cartesian theory of mind/body division and disparity, and the notion that if we are thus fragmented, we can achieve a greater sense of social (and possibly cultural) value.

\footnotetext{
*Assistant Professor/Program Director of Dance, Nazareth College, USA.

1. Janice Ross, Moving Lessons (Madison, WI: The University of Wisconsin Press, 2000), 14.
} 
This was the reigning, if not conscious, ideology of the trend in physical culture that took place during the latter half of the $19^{\text {th }}$ century. The emergence of the new physical culture, promoting a Hellenistic aesthetic of the body and a concern for health and exercise, provided a timely opportunity for the teachings of the Delsarte System of Expression, taught as a series of aesthetic gymnastics by Francois Delsarte's American protégés. ${ }^{2}$

As Ross states, "The growing popularity of Delsartism among women in the United States paralleled women's increasingly frequent ventures into the public arena." 3 The emphasis of Delsarte's theories on the socially sanctioned and even coveted skills of bodily and verbal communication provided an outlet for women who were primed for change. This growing practice of public physicality, expression and performance provided a fragile but fertile foundation from which modern dance was soon to grow.

It was in the midst of this period of change that Isadora Duncan (18771927) was coming of age. Dance writer Gerald Jonas comments: "Duncan's gestural vocabulary showed the influence of Delsartism, but even more important to her development was the fact that Delsarte's summons to free the body from all unnecessary constraints had already been heard in the salons of New York and Newport."4

To the women in the audience, Ross observes that Duncan "represented a magnificent amplification of the ideals of new physical health and sanctioned pleasure in bodily movement. ${ }^{5}$ Mark Franko in his book Dancing Modernism/ Performing Politics states: "Duncan performed women's rights; Duncan's dance was a transparent medium through which her personality sent a message of social reform."6 It seems her dancing and her life both exemplified a convergence of the numerous battlegrounds for acknowledgement and empowerment that women of the early $20^{\text {th }}$ century faced: dress reform, health reform, public access, equality, and autonomy in all spheres of life.

But here I raise the question: How did Duncan position herself as a female dancing body, and do so with relative success, during this time period? I would like to explore some hypotheses on why her influence on the body and dance was so prodigious. Susan Manning in her article, "The Female Dancer and the Male Gaze: Feminist Critiques of Early Modern Dance," argues that a communal sense of empowering kinesthesia was what removed Duncan's dancing from the male gaze, and separated it from the "body as object" design

2. Francois Delsarte. Retrieved from http://www.musikinesis.com/Delsarte.

3. Ross, Moving Lessons, 20-21.

4. Gerald Jonas, Dancing: the Pleasure, Power, and Art of Movement (New York: Harry N. Abrams, Inc., 1992), 194-195.

5. Ross, Moving Lessons, 14.

6. Mark Franko, Dancing Modernism/Performing Politics (Indianapolis: Indiana University Press, 1995), 7. 
of previous dance forms. Manning goes on to say: since "spectators had experienced the same movement techniques ... - Delsarteanism and aesthetic gymnastics - their kinesthetic response was particularly intense and led more than a few to identify the dancer's flow of bodily motion as reflective of their own." ${ }^{7}$ By the shared knowledge of the familiar gestures and movements, the audience was able to associate with and connect to the performer, rather than simply observing the "spectacle" and applying a detached and critical gaze. "In other words, the kinesthetic power of Duncan's dancing countered not only the voyeuristic gaze but also ... essentialism."8

Amy Koritz echoes this idea with a similar "removal" theory: that by endowing herself with the ability to project the spiritual through her dancing body, Duncan removed the sexual stigma. "Duncan attempted to convey a spiritual state, making her stage presence, or "personality," at best a medium rather than an end in itself, and ideally something to be forgotten altogether at the height of the aesthetic experience."9 Janice Ross identifies this same sentiment:

It was the idealism her art suggested rather than the reality of her flesh ... that she wanted audiences to attend to. In opposition to the long-standing theatrical notion of a woman onstage always being an eroticized figure, Duncan opened the possibility for the female dancing body to carry other meanings and for it to be a medium for other values and aspirations. ${ }^{10}$

Duncan herself even alludes to this theory of "bodily removal," in writing about her approach to dance, "by which the body becomes transparent and is a medium for the mind and spirit."11 By focusing on the naturalness of the body and its role as a conduit of expression, Duncan negates the fragmentation and mechanization of the body and attempts to mend the rift of the mind/body dualism. However, in order to reconstruct an image of New Woman and New Dance, the female body necessarily had to vanish (in order to be reborn).

Through her dancing and living example, Franko claims that: "Duncan displaces (other) powerful binaries such as inner/outer and private/public but also female/male, nature/culture, labor/capital."12

7. Susan Manning, "The Female Dancer and the Male Gaze: Feminist Critiques of Early Modern Dance," in Meaning in Motion, ed. Jane C. Desmond (Durham: Duke University Press, 1997), 163.

8. Ibid., 159-161.

9. Amy Koritz, Gendering Bodies/Performing Art: Dance and Literature in Early Twentieth-century British Culture (Ann Arbor: University of Michigan Press, 1986), 50.

10. Ross, Moving Lessons, 16.

11. Isadora Duncan, quoted in Lincoln Kirstein, Dance: A Short History of Classic Theatrical Dancing (New York: G.P. Putnam's Sons, 1935), 271.

12. Franko, Dancing Modernism/Performing Politics, 14. 
Her career as a self-producing female soloist effectively challenged the separation of public and private spheres that immured women in the confines of domesticity. ... Although opposed to the separation of these spheres, Duncan also relied on their segregation to dramatize her opposition. ${ }^{13}$

Similar to this idea of sliding between realms, Duncan was able to limn the ideal of the New Woman by traversing the turn-of-the-century polarities of the sentimental and the sensational. Though proceeding to break boundaries with her sensational lifestyle, she also called upon and borrowed the popular sentimental notions of heroism, femininity, and purity when referring to her vision of dancing. Though censured by many for her unencumbered style of dress and emancipated gestures, she shrewdly aligned herself with the Neoclassical models of the ancient Greeks, and thus substantiated her attire as fashion and her dancing as art. Jonas writes: "Her costume, antique in its associations, was also deliciously modern ... . To (the audience of society women), the loosely clad Duncan, striking poses from quattrocento paintings and Greek sculpture, must have seemed an incarnation not just of Art and Beauty but of Freedom itself."14

In Duncan's dance, the Body represented the medium of art. The triads of physical, mental and emotional sources were fused together to convey a message through Duncan's choreography, refuting the notion of the body being a separate entity and existing secondarily to the mind. This triangulation was also inherently housed in the body of Woman, a vessel well suited to providing the timely chrysalis for the emergence of modern dance. As author Susan Manning says:

Whereas the representational frames reiterated and updated preexistent images of gender ..., the kinesthetic dimension introduced a new image of the female body in motion that was without precedent. ${ }^{15}$

Thus, by a serendipitous amalgamation (and possible removal) of culturally oppositional binaries (mind/body, sensational/sentimental, male/female, nature/ culture, public/private), Duncan forged a lasting place for herself both in the history of dance and in the history of the female body.

13. Ibid., 2.

14. Jonas, Dancing: the Pleasure, Power, and Art of Movement, 195.

15. Manning, "The Female Dancer and the Male Gaze:, 164. 


\section{Signs of the Time}

In the early part of the $20^{\text {th }}$ century, the gestural look and intent of modern dance began to gradually change. The entire notion of performance was underscored and informed by the current ideas of naturalism, realism, and Freud's symbolism of the psyche. ${ }^{16}$

Using an abstractly symbolic language based in human gesture, Martha Graham (1894-1991) created a new movement vocabulary with which to express her ideas. As Myron Howard Nadel describes it: "Graham dug into the physical basis of drama and found movements that captured the emotional essence of each moment."17 These forceful, jarring movements were a marked divergence from the overtly Romantic and genteel gestures of Duncan. Unlike the grand, lyrically expressive gestures of Duncan, Graham sought to portray (often dark) emotion and the prototypical frailties and strengths of the human spirit through the sparse, emphatic, and abstract movements of a harsh body composition.

Though perhaps not as directly or consciously expressed through her dances as the socially reflective themes, did Graham emanate a politics of the body through her movements? Politics consists of "social relations involving authority or power,"18 and the term "body politics" looks at these discursive cultural and historical forces and how they are inscribed upon, reframed and reformed through the site of the body. I want to delve into the issue of Graham's body politics at this time, as this is intrinsically tied to the gestures and physicality assumed in her performance. Though the intent of some of Graham's choreography may have been to communicate the universal, gendered "essence" of a female character, this is a theme presumably based upon a Jungian philosophy and Surrealist aesthetic, not necessarily a political, corporeal stance. What I wish to clarify is the difference between the intended purpose or design of the choreographic message and the implied political content contained and conveyed by the body itself through its "techniques" of discipline. ${ }^{19}$

16. Paul Brians, Realism and Naturalism (copyright March 1998). Retrieved from goo.gl/C9mDWg. [Accessed: 23 June, 2007]

17. Myron Howard Nadel, \& Marc Raymond Strauss, The Dance Experience Insights into History, Culture, and Creativity (Hightstown, NJ: Princeton Book Publishers, Inc., 2003), 120.

18. Politics, defined on the die.net dictionary website. Retrieved from goo.gl/ Fygj7s. [Accessed: 28 June, 2007]

19. The term "techniques" makes reference to the theory of "Techniques of the Body" by Marcel Mauss ("Les Techniques du corps," this term was first introducted at a lecture given at the Société de Psycholgie in France, 1934) whereby bodily actions are instituted through cultural imitation and education via socio-psycho-biological means (Marcel Mauss, "Techniques of the Body," in Incorporations (ed.), Jonathan 
I propose that though the choreography and characterizations in (some of) Graham's work may have displayed essentialized images of women, the bodily attitudes executed through her choreography carry a different message. Examined through a historically specific lens, I believe the bodily gestures manifested by Graham and her dancers were socially and discursively constructed, and representationally disruptive in their respective time period.

In her article, "A Technique for Power: Reconfiguring Economies of Energy in Martha Graham's Early Work," Dee Reynolds applies sociologist Pierre Bourdieu's theory of habitus to Graham's specific gestural vocabulary and the daily physical practice required to learn and perform it. Reynolds states that the effect of Graham's new effort paradigms extended beyond the field of dance, and that the display of physical power did subvert the existing regimes of representation for women. Reynolds equates the physical vigor and control of Graham's technique, (her discipline of the body), with a pursuit for female empowerment. ${ }^{20}$

Henrietta Bannerman, in "An Overview of the Development of Martha Graham's Movement System (1926-1991)" also articulates the disruptive power of Graham's bodily politics: "Not only did she break the rules for how the dancing body should move in time and space but she challenged accepted traditions relating to the female body and its presentation as an expressive medium."21

This reconfiguration and re-conception of the female dancing body was nearly as difficult in Graham's time as it had been in Duncan's day. Graham had a vision for modern dance to be accepted as a high art form, and strove to remove it from the commercial trappings of popular entertainment. She also wanted to embody a distinctly American voice, diverging from the far-away cultures, exoticism, emulation, appropriation and mysticism she was trained in at Denishawn. Amy Koritz in her article "Re/Moving Boundaries" expounds upon the logic for this aesthetic choice:

Crary and Sanford Kwinter (NY: Urzone, Inc., 1992), 455-477). Discipline is a reference to Michel Foucault's theories in Discipline and Punish: The Birth of the Prison, originally published in French in 1975, which reflect upon the (corporeal and carceral) methods of power and knowledge through which humans are controlled and indoctrinated in modes of acceptable behavior (Michel Foucault, Discipline and Punish: The Birth of the Prison (NY: Vintage Books, 1977)).

20. Dee Reynolds, "A Technique for Power: Reconfiguring Economies of Energy in Martha Graham's Early Work," Dance Research: The Journal of the Society for Dance Research 20, no. 1. (Summer, 2002): 26-27.

21. Henrietta Bannerman, "An Overview of the Development of Martha Graham's Movement System (1926-1991)," Dance Research: The Journal of the Society for Dance Research 17, no. 2, (Winter 1999), 9. 
The legitimacy of dance as an elite art was still uncertain, and any association of concert dance with low status dance forms would have threatened this goal. The perceived sensuality of (popular and exotic) movement also would have given a suspicious public reason to dismiss the seriousness of women dancers who used such movements in work they wished to define as art. ${ }^{22}$

This statement also suggests that female modern choreographers were still struggling against a cultural inclination to project them as objects of male desire. Julia Foulkes proposes that Graham surmised that: "Sexual movements signified lower art, and modern dancers' attempt at sexlessness revealed the gender, class, and racial prejudices that codified a cultural hierarchy of high and low ...." ${ }^{23}$ By aligning herself with the avant-garde artistic movements of the time, and divesting her movement of any hint of sensual or exotic indulgence, Graham hoped to elevate modern dance to an elite status. The trend to move away from emotive gesture also had its reasoning. Mark Franko states that: "... Martha Graham's lack of personal emotion in her early concert appearances can be linked to a critical perception that Duncan's emotionalism was a "feminine" weakness."24 Following cues of disparaging and passé images of (feminine) emotional display, Graham intuited that the "removal" of the body that had worked for Duncan in her time was no longer a sound approach with which to propel modern dance (and the female body) forward. A new (bodily and aesthetic) stance was called for.

"The first decade or so of Graham's career was characterized by her redefinition of dance and of the female body," 25 states Bannerman. This view projects Graham as moving to a new point on the feminist spectrum. Franko agrees, asserting that "Graham ... was feminist and purposefully avoided identification with the feminine as powerless." 26 In wanting to overcome the entrenched traditions and ever-present dualisms of mind/body, male/female, objective/subjective, rational/emotional, Graham discarded Duncan's method of attempting to blur the boundaries through bodily disappearance. Instead she pushed to cross the divide by incorporating those qualities long-thought to be solely the domain of men, and to some extent, eschewing those

22. Amy Koritz, "Re/Moving Boundaries - From Dance History to Cultural Studies" in Moving Words - Rewriting Dance, ed. Gay Morris (London/New York: Routledge, 1996), 97.

23. Julia L. Foulkes, Modern Bodies: Dance and American Modernism from Martha Graham to Alvin Ailey (Chapel Hill and London: The University of North Carolina Press, 2002), 48.

24. Franko, Dancing Modernism/Performing Politics, xii.

25. Bannerman, "An Overview of the Development of Martha Graham's Movement System (1926-1991)," 10.

26. Franko, Dancing Modernism/Performing Politics, 44. 
characteristics associated with femininity. Foulkes writes of this complicated, seemingly androgynous trend to subvert,

... the heterosexual framework of desire between female performer and male audience member that defined ballet and show dancing. (Graham) challenged conventional perceptions of femininity on stage by exposing the serious expressive possibilities of bodies. Participants, critics, and some dance historians proclaimed this kind of dance as "sexless," but, more accurately, it was women taking on what many believed were masculine attributes, thereby complicating the perceived categories of male and female physical gestures and appearances. ${ }^{27}$

Acknowledging the uneasiness felt by audiences and critics, Graham extracts herself as performer from the presupposed associations derived from the image of her female body on stage, saying:

I was outside the realm of women. I did not dance the way that people danced ... . In many ways I showed onstage what most people came to the theater to avoid. ${ }^{28}$

Thus, by incarnating the "grotesque" female, Graham was able to lay claim to new forms of embodiment in dance, as well as to stake out new spaces for bodily comportment at the margins of what was deemed socially acceptable for women in performance. In searching for an American identity in dance, and in seeking elite approval for the fledgling form of art, Graham herself described it in gendered terms: "America is cradling an art that is destined to be a ruler, in that its urge is masculine and creative, rather than imitative."29 This masculinist aesthetic was a key motif to the new direction she envisioned for modern dance. By incorporating the characteristics of male/objective/rational, Graham sought acceptance for her art form and herself as an artist.

This notion seems distinctly anti-feminist, but given the times, and the tenuous new heterosocial atmosphere in America it is not surprising. Foulkes contextualizes this phenomenon, writing that:

Modern dance solidified in the decade following the passage of women's suffrage in $1920 \ldots$. While female modern dancers did not ardently embrace specific goals about changing the status of women, their roles as

27. Foulkes, Modern Bodies: Dance and American Modernism, 46.

28. Martha Graham, Blood Memory (New York: Doubleday, 1991), 114 quoted in Koritz, "Re/Moving Boundaries, 97.

29. Martha Graham, "Seeking an American Art of the Dance," in Revolt in the Arts, ed. O.M. Sayler (New York: Brentano's, 1930), 249 quoted in Koritz, "Re/Moving Boundaries, 97. 
choreographers, performers, teachers, and directors of companies placed them in the middle of ongoing debates about what women were capable of, the differences and similarities between men and women, and the role of women as creators of and commentators on American culture. ${ }^{30}$

In light of these socio-cultural ambiguities, we can view Graham's espousal of masculinist aesthetics as a forceful swing in the opposite direction from the feminine qualities which were at best socially in limbo, and at worst, disreputable. Franko comments on this delicate balance: "The Americanness she sought to discover/embody at this early stage of her choreographic career was a paradoxical construct: ... both female and male."31 While Graham's bodily and artistic location during this early period is complex and convoluted, this resultant gender border-crossing allowed her to infiltrate the patriarchal world of high art and yield a new representation of the female body.

Graham was actually not "outside" the realm of women, despite reductivist, emotivist or essentialist strategies aiming to place her in the margins of the (feminist) history of the female body and dance. Her choreographic tendencies and narratives should not be confused with her body politics, her gestures themselves conveying an implicit message of female empowerment and signs of the time.

\section{New Frames of Mind and Body}

From the 1940s on, Martha Graham's (as well as other modern choreographers') approach to choreography began to evolve in a new direction. Induced by nationalistic trends of unity, the artistic urge to challenge the norm and cultivate the diverse individual gave way to statements of heroism and congruity. Foulkes writes: "By the early 1940s the call to patriotism in the midst of World War II reflected larger societal changes, and modern dancers found fewer opportunities to broadcast their challenging views of America's past and present." 32

This bled into a desire for conformity and normality in the 1950s, which helped to assuage the trauma experienced from the Depression, World War II, and the Korean War.

30. Foulkes, Modern Bodies: Dance and American Modernism, 29.

31. Franko, Dancing Modernism/Performing Politics, 54.

32. Foulkes, Modern Bodies: Dance and American Modernism, 155. 
Most of the internal conflicts that had developed in earlier decades like women's rights, civil rights, and imperialism were relatively suppressed or neglected during this time as a world returning from the brink hoped to see a more consistent way of life as opposed to the radicalism of the 1930s and 1940s. ${ }^{33}$

The modern choreographers of the 1950s, unlike their politically indignant predecessors, also adhered to this escapist strategy. Foulkes writes that: "Instead of using dance to amplify the meaning of headlines, (this) ... generation moved away from headlines altogether." 34

This was also partly due to the "Red Scare," which induced new pressures on political affiliations and freedom of speech. In the 1950's, the women's movement appeared all but abandoned as the popular cultural and projected images on television promulgated the "feminine mystique" theory of domesticity and family-first, representations that seemed indicative of "woman's place."35 However, under the appealing surface of American suburbia, civil rights issues were broiling and activists were campaigning for equality in all facets of life despite strong opposition, especially in the south where segregation maintained a tight hold on society.

A rebellion was brewing in the arts, as well. After World War II, with the country in the throes of McCarthyism, the arts had been affected by a period of extreme censorship. The use of abstraction allowed artists to make statements that were not necessarily visible or cohesive to anyone but other "insiders," and thus the movement of Abstract Expressionism burst forth. Merce Cunningham applied the Abstract Expressionist's use of idiosyncracy to dance - removing literal, staged, and dramaturgical associations from his own choreography, distilling it to a pure form of abstract movements. Though Cunningham's choreographic and performance methods were clearly radical, his actual gestures were somewhat conformist, retaining traces of earlier styles. Gerald Jonas in Dancing writes that:

... many of his movements betrayed his familiarity with conventional dance technique, including ballet and the Graham technique. His work conveyed the feeling that he was making "art," which was something different from life, something just a little bit privileged ... . ${ }^{36}$

33. 1950's, Wikipedia, [online database], (copyright April 2007). Retrieved from goo.gl/5qJJT. [Accessed: 18 July, 2007).

34. Foulkes, Modern Bodies: Dance and American Modernism, 171.

35. The Feminine Mystique was a controversial text written in 1963 by Betty Friedan. The book exposed and attacked the notion that women could only find worth and meaning through the bearing and raising of children and the care of the household. This book is often credited with spurring the feminist movement of the 1960s.

36. Jonas, Dancing: the Pleasure, Power, and Art of Movement, 230. 
Influenced by his progressive approaches to dance-making and use of non-traditional dance presentation, a new generation of choreographers set off to make bodily statements about "life" rather than the traditional notion of creating "art."

During the 1960's, the new vanguard of modern dancers paralleled the visual art movement of Pop art and the anti-elitist philosophy of Assemblage, presenting the body and gestures in ways that were antithetical to previous practices. This interest in not only arranging but also revealing the mundane and quirky in new ways caused a latitudinal reconsideration of cultural aesthetics and values, and a redefinition of the term "art."

No longer did dancing appear to be the realm of elite and highly trained technicians. The disciplining of the body required in the technique of the modern dance predecessors no longer seemed relevant or necessary for the creation of a dance. The radical exposition of everyday gesture echoed the feelings of a growing liberalism, push for equality, and recognition of individuality in the nation. Yvonne Rainer was one of the forerunners of this new genre of choreographers. Incorporating everyday movements, sounds and items into her choreography, she began to gradually move away from the theatrical and to investigate neutral objectivity.

Susan Leigh Foster verbalizes Rainer's novel display of movement: "by disengaging actions from their functional context, ... viewers (were able) to attend closely and perhaps for the first time to simple activities ... . The care and detail with which dancers manipulated ... objects gave their actions a trenchant eloquence that transcended both their pedestrian origins and the iconoclastic message of the dance." ${ }^{17}$ This new approach to menial movement as performance crystallized in the 1966 piece, Trio A. Continuing to peel away the layers of theatricality, in approaching this work, Rainer adopted the unaffected physical attitude of performing tasks. Sally Banes hails Trio $A$ as the marked divergence into true post-modernism, the singular work that inspired a new generation of choreography. ${ }^{38}$

The general distinction of the broader postmodern art movement was a reference to a cultural, intellectual, or artistic state lacking a clear central hierarchy or organizing principle and embodying extreme complexity, contradiction, ambiguity, diversity, and analytic interconnectedness or interreferentiality. Postmodernism inferred a reaction to and rejection of previous mores, displacing monolithic ideologies, revealing the artificiality of style, and refuting the traditional valuing and categorizing of "high" and "low" art. This retraction of established hierarchy and inclusion of diversity was evident even in the treatment of gender (and aided by the national rise of

37. Susan Leigh Foster, Reading Dancing - Bodies and Subjects in Contemporary American Dance (Berkeley, Los Angeles: University of California Press, 1986), 172.

38. Sally Banes, Terpsichore in Sneakers (Boston: Houghton Mifflin Company, 1979). 
feminism and equal rights lobbying in the sixties). The postmodern dancers used this cultural impetus by attempting to blur gender distinctions, often wearing loose pants and shirts that left the body's outline ambiguous and undefined.

This gender-blending continued in other areas of postmodern dance, removing the sexual stigma so often placed on the body in view. The conventional role and image of "the feminine" was ignored, questioned, or blatantly refuted by the postmodern dancers. In Dancing Women: Female Bodies on Stage, Banes comments that "... dances of the early Sixties operated like The Feminine Mystique to present a criticism of the status quo in terms of gender relations ... in ways that were shocking to contemporary sensibilities - both in the dance tradition ... and in the larger arena of socio-cultural conventions." 39 These choreographers performed, and therefore validated, representations of non-conformist, gender-neutral, and de-sexualized female bodies.

I want to further investigate this idea of the "desexualized" 1960s postmodern body, to penetrate beneath the seemingly androgynous surface, for in reality, the unisex apparel and the non-gender-defined roles and gestures carried a political meaning of their own. Part of the goal (or rather a means to an end), of feminism at the time was the destabilization of entrenched gender ideologies. In her text, Shaky Ground, author Alice Echols investigates the American cultural experience of feminism during the 1960s.

Central to the revisionary project of the women's liberation movement was the desire to render gender meaningless, to explode it as a significant category. In the movement's view, both masculinity and femininity represented not timeless essences, but rather "patriarchal" constructs ... . The "colonized" status of women's bodies became the focus of much movement activism, ... (and the female body, therefore, became a) ... site of political contestation. ${ }^{40}$

Elizabeth Dempster in "Women Writing the Body: Let's Watch a Little How She Dances," reflects upon the effect of this petition for gender-neutrality in postmodernism, remarking that in this approach to dance, "the specificity of the female body is obscured ... difference is reduced to sameness." 41 Though viewers could (presumably) still accurately distinguish gender, this praxis of indistinction

39. Banes, Dancing Women: Female Bodies on Stage (London and New York: Routledge, 1998), 216-217.

40. Alice Echols, Shaky Ground: The Sixties and its Aftershocks (New York: Columbia University Press, 2002), 84.

41. Dempster in Grafts: Feminist Cultural Criticism, ed. S. Sheridan (London: Verso, 1988), 50, quoted in Helen Thomas, "Do You Want to Join the Dance? Postmodernism/ Poststructuralism, the Body, and Dance" in Moving Words: Re-writing Dance, ed. Gay Morris (London and New York: Routledge, 1996), 82. 
(while not realistically successful in reducing to sameness), did provide a means for critical appraisal of gender codes. The constructs of both gender and dance were questioned and subverted in postmodernist choreography. Helen Thomas in her article "Do You Want to Join the Dance? Postmodernism/Poststructuralism, the Body, and Dance" comments:

... postmodern dance ... does not constitute a "newly defined dance language" but is rather an "interrogation of that language itself" (51) and herein lies its potential to intervene in and subvert the conventions of patriarchal discourse. The postmodern body is not fixed, but is constantly in flux, adapting and transforming itself through its engagement with the world. The "writing" of the body in postmodern dance ... is partial, conditional, temporal; as it is being written, so it is erased. This means that the body in postmodern dance ... and by extension the "feminine," "is unstable, fleeting, flickering, transient - a subject of multiple representations" (49).42

In postmodern dance, choreographers/dancers attempted to discredit both the conventional, sexualized presumption of "female" and the accepted notion of disciplined techniques of "dance" by offering new situations and representations of the body that critically intervened in the process of signification.

Thus the feminist conception and performative objective of the body was again rendered anew in the avant garde dance. Rather than serving as a vessel for the expression of the soul (Duncan), or a visually abstract, symbolic signifier (Graham), the body became secondary to the movement itself, the dance becoming a praxis on display rather than a tool for communication. In reviewing Rainer's reflexive process of dance-making, Foster summarizes her distinction: "Rainer suggests that by returning to narrative structures in which the body would necessarily refer to things other than itself while disrupting those narrative structures as they unfold in the performance, the performance can unmask the body's ideological message and thus allow viewers to contemplate the body as a signifying practice."43

It is difficult, nigh impossible, to separate the body from the gesture, either visually or philosophically. Thus, without the attempt to neutralize the gendered body in postmodern dance, the purposefully insignificant gesture would not have had the significant impact that it did in the 1960s. In this novel approach to choreography, the body (and its communicative properties) was interrupted and subjugated by the political power of movement itself.

Rather than a sexualized yet disappearing body (Duncan), or a gendercrossing, trans-sexualized body (Graham), Rainer rendered the body patently

42. Thomas, "Do You Want to Join the Dance?," 83.

43. Foster, Reading Dancing - Bodies and Subjects, 259. 
asexual and secondary, seemingly a blank slate or apparatus used for the pragmatic execution of undiluted movement. The focus was on the individualistic kinesthetic statement, and relied on the participation of the viewer to extract an interpretation. The grand, Romantic gesture of Duncan or the universal, archetypal gesture of Graham was now supplanted by the objective, unrefined, pedestrian gesture. But to be clear: the postmodernist's pedestrian gesture, however simplistic its appearance, encapsulated a wealth of symbolism, both political and philosophical. Thus, upon deeper investigation, the notion of a non-gender-biased utopia and the incorporation of seemingly banal gestures in 1960s modern dance, in fact, leads the viewer instead into selfreflexive and critical analyses of aesthetic, gender, social and political discourses.

\section{Parting Gestures}

Other inquiries arise and still beg to be answered in the continuing quest for understanding and defining gesture and gender, though it is not within the scope of this paper. After examining the theoretical, cultural and historical markings on the bodies and markings left by the bodies of work of Duncan, Graham, and Rainer, we can conclude that a gesture's production must inherently contain the intertextuality and interreferentiality of the performer's construction of "self," as well as the correspondingly singular interpretation by the viewer. Susan Foster emphasizes this causality in her article "The Signifying Body: Reaction and Resistance in Postmodern Dance:"

Because ... performances emphasize the shifting identities of body and subject, they permit an investigation of the ethics of body-subject interaction ... the political messages are to be found in the dances themselves, in the choreographic codes and conventions through which the dance organizes itself and refers to the world. ${ }^{44}$

Especially in this age of mass media, as we are increasingly globally exposed to these codes of human conduct, there is much research to be done on the significance of dance/gesture and its causal relationship with body politics. I have explored but a small aperture of historical knowledge through my feminist lens. However, in focusing on these three iconic modern dance choreographers, and assembling and critically sifting through various viewpoints on the effects that gender, art, science, politics and social culture had on the creation and interpretation of these bodily semiotics during their respective eras, I hope I have shed some further light.

44. Foster, "The Signifying Body: Reaction and Resistance in Postmodern Dance," Theatre Journal 37, no. 1, "Theory" (March, 1985): 48. 


\section{Bibliography}

Bannerman, Henrietta. "An Overview of the Development of Martha Graham's Movement System (1926-1991)." Dance Research: The Journal of the Society for Dance Research 17, no. 2, (Winter 1999), 9-46.

Banes, Sally. Terpsichore in Sneakers. Boston: Houghton Mifflin Company, 1979.

Banes, Sally. Dancing Women: Female Bodies on Stage. London and New York: Routledge, 1998.

Echols, Alice. Shaky Ground: The Sixties and its Aftershocks. New York: Columbia University Press, 2002.

Franko, Mark. Dancing Modernism/Performing Politics. Indianapolis: Indiana University Press, 1995.

Foster, Susan Leigh. "The Signifying Body: Reaction and Resistance in Postmodern Dance." Theatre Journal 37, no. 1, "Theory" (March, 1985): 4564.

Foster, Susan Leigh. Reading Dancing - Bodies and Subjects in Contemporary American Dance. Berkeley, Los Angeles: University of California Press, 1986.

Foulkes, Julia L. Modern Bodies: Dance and American Modernism from Martha Graham to Alvin Ailey. Chapel Hill and London: The University of North Carolina Press, 2002.

Foucault, Michel. Discipline and Punish: The Birth of the Prison. NY: Vintage Books, 1977.

Jonas, Gerald. Dancing: the Pleasure, Power, and Art of Movement. New York: Harry N. Abrams, Inc., 1992.

Kirstein, Lincoln. Dance: A Short History of Classic Theatrical Dancing. New York: G.P. Putnam's Sons, 1935.

Koritz, Amy. Gendering Bodies/Performing Art: Dance and Literature in Early Twentieth-century British Culture. Ann Arbor: University of Michigan Press, 1986.

Koritz, Amy. "Re/Moving Boundaries - From Dance History to Cultural Studies." In Moving Words - Rewriting Dance, edited by Gay Morris. London/ New York: Routledge, 1996.

Manning, Susan. "The Female Dancer and the Male Gaze: Feminist Critiques of Early Modern Dance." In Meaning in Motion, edited by Jane C. Desmond, 153-166. Durham: Duke University Press, 1997.

Mauss, Marcel. "Techniques of the Body." In Incorporations, edited by Jonathan Crary and Sanford Kwinter, 455-477. NY: Urzone, Inc., 1992.

Nadel, Myron Howard, \& Strauss, Marc Raymond. The Dance Experience Insights into History, Culture, and Creativity. Hightstown, NJ: Princeton Book Publishers, Inc., 2003. 
Reynolds, Dee. "A Technique for Power: Reconfiguring Economies of Energy in Martha Graham's Early Work." Dance Research: The Journal of the Society for Dance Research 20, no. 1. (Summer, 2002): 3-32.

Ross, Janice. Moving Lessons. Madison, WI: The University of Wisconsin Press, 2000.

Thomas, Helen. "Do You Want to Join the Dance? Postmodernism/ Poststructuralism, the Body, and Dance." In Moving Words: Re-writing Dance, edited by Gay Morris, 63-87. London and New York: Routledge, 1996. 